\title{
Local Induction Heating Capabilities of Zeolites Charged with Metal and Oxide MNPs for Application in HDPE Hydrocracking: A Proof of Concept
}

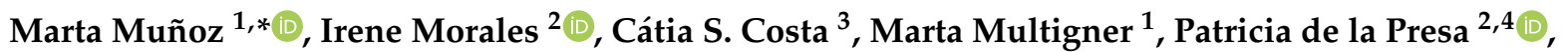 \\ Jose M. Alonso $^{2,5}$, João M. Silva ${ }^{3,6} \mathbb{D}$, Maria do Rosário Ribeiro ${ }^{3} \mathbb{D}$, Belén Torres ${ }^{1}$ and Joaquín Rams ${ }^{1} \mathbb{D}$ \\ 1 Department of Applied Mathematics, Materials Science and Engineering and Electronic Technology, \\ Rey Juan Carlos University, 28933 Madrid, Spain; marta.multigner@urjc.es (M.M.); belen.torres@urjc.es (B.T.); \\ joaquin.rams@urjc.es (J.R.) \\ 2 Institute of Applied Magnetism, UCM-ADFI-CSIC, 28230 Las Rozas, Spain; irenemorales@ucm.es (I.M.); \\ pmpresa@ucm.es (P.d.1.P.); jm.a.r.0@csic.es (J.M.A.) \\ 3 Centro de Química Estrutural (CQE), Instituto Superior Técnico, Universidade de Lisboa, \\ 1049-001 Lisbon, Portugal; catia.s.costa@tecnico.ulisboa.pt (C.S.C.); jmsilva@deq.isel.ipl.pt (J.M.S.); \\ rosario@tecnico.ulisboa.pt (M.d.R.R.) \\ 4 Department of Materials Physics, Complutense University of Madrid, 28040 Madrid, Spain \\ 5 Material Science Institute of Madrid, CSIC, 28049 Madrid, Spain \\ 6 Instituto Superior de Engenharia de Lisboa (ISEL), Instituto Politécnico de Lisboa, 1959-007 Lisboa, Portugal \\ * Correspondence: marta.munoz@urjc.es
}

\section{check for} updates

Citation: Muñoz, M.; Morales, I.; Costa, C.S.; Multigner, M.; de la Presa, P.; Alonso, J.M.; Silva, J.M.; Ribeiro, M.d.R.; Torres, B.; Rams, J. Local Induction Heating Capabilities of Zeolites Charged with Metal and Oxide MNPs for Application in HDPE Hydrocracking: A Proof of Concept. Materials 2021, 14, 1029. https:// doi.org/10.3390/ma14041029

Academic Editor: Gennady L. Gutsev

Received: 19 January 2021

Accepted: 18 February 2021

Published: 22 February 2021

Publisher's Note: MDPI stays neutral with regard to jurisdictional claims in published maps and institutional affiliations.

Copyright: (c) 2021 by the authors Licensee MDPI, Basel, Switzerland. This article is an open access article distributed under the terms and conditions of the Creative Commons Attribution (CC BY) license (https:// creativecommons.org/licenses/by/ $4.0 /)$.

\begin{abstract}
Zeolites are widely used in high-temperature oil refining processes such as fluid catalytic cracking (FCC), hydrocracking, and aromatization. Significant energy cost are associated with these processes due to the high temperatures required. The induction heating promoted by magnetic nanoparticles (MNPs) under radio frequency fields could contribute to solving this problem by providing a supplementary amount of heat in a nano-localized way, just at the active centre site where the catalytic process takes place. In this study, the potential of such a complementary route to reducing energetic requirements is evaluated. The catalytic cracking reaction under a hydrogen atmosphere (hydrocracking) applied to the conversion of plastics was taken as an application example. Thus, a commercial zeolite catalyst (H-USY) was impregnated with three different magnetic nanoparticles: nickel $(\mathrm{Ni})$, cobalt $(\mathrm{Co})$, maghemite $\left(\gamma-\mathrm{Fe}_{2} \mathrm{O}_{3}\right)$, and their combinations and subjected to electromagnetic fields. Temperature increases of approximately $80^{\circ} \mathrm{C}$ were measured for H-USY zeolite impregnated with $\gamma-\mathrm{Fe}_{2} \mathrm{O}_{3}$ and $\mathrm{Ni}-\gamma-\mathrm{Fe}_{2} \mathrm{O}_{3}$ due to the heat released under the radio frequency fields. The potential of the resulting MNPs derived catalyst for HDPE (high-density polyethylene) conversion was also evaluated by thermogravimetric analysis (TGA) under hydrogen atmosphere. This study is a proof of concept to show that induction heating could be used in combination with traditional resistive heating as an additional energy supplier, thereby providing an interesting alternative in line with a greener technology.
\end{abstract}

Keywords: Zeolite; plastic waste; hydrocracking; hyperthermia; magnetic nanoparticles (MNPs); electromagnetic fields

\section{Introduction}

Plastic production increased by more than 20-fold from 1964 to 2018 with an annual output of $359 \mathrm{Mt}$, [1]. This value is expected to reach 18,000 Mt in 2050 [2]. Despite the contribution of plastics to the economic evolution of the world, their current production and use patterns are leading to serious environmental problems [3].

Hydrocracking technology has been recognized as a very promising solution for managing plastic waste since it allows plastic feedstock to be converted into valuable products, thus removing heteroatoms that may exist in waste plastic, reducing the amount of olefins 
and aromatics in the final products, and reducing the coke precursors responsible for the catalyst deactivation in one single process [4,5]. Typically, the hydrocracking catalysts are bifunctional, comprising an acidic function responsible for the cracking and isomerization reactions, and metal centers where hydrogenation-dehydrogenation reactions take place [6]. The acidic function is generally given by amorphous oxides (silica-alumina), zeolites, strong solid acids (sulfated zirconia) or a combination of these materials. Nevertheless, zeolites are by far the most applied materials because they have unique properties: high thermal stability, high strength and number of acidic sites, high external surface area, and an unequalled pore channel system, all of which make them suitable catalysts for plastic conversion [7-11]. In turn, the metallic function is usually represented by a noble metal (palladium or platinum), a non-noble metal of group VI-A (molybdenum or tungsten) or group VIII-A (cobalt or nickel), according to the periodic table [5].

The conversion of a single type or a mixture of plastics over bifunctional catalysts $[7,8,12-18]$ by hydrocracking has been reported by several authors. Their findings show that the presence of a catalyst has a beneficial effect in the reaction, decreasing the temperature and the time required to achieve high conversions and allowing enhancing the quality of the gas and liquid products. Unfortunately, the energy requirements associated with this process are still high.

In order to address this problem, magnetic nanoparticles (MNPs) under radio-frequency fields are proposed for use as nanoheaters. MNPs offer a simple way of achieving high, fast and nano-localized temperatures [19] that are able to participate in these processes as an additional energy supplier, thus decreasing significantly the conventional heating requirements.

Numerous studies in the literature discuss the use of high-frequency fields for heating MNPs in different areas as medical applications (e.g., cancer therapies) [20,21], engineering and technological applications like water electrolysis reactions [19], $\mathrm{CO}_{2}$ hydrogenation and methanation [22,23], and functions related to polymeric materials like induction heating polymerization of molecularly imprinted polymers [24]. Electromagnetic fields in combination with MNPs are also used as heat sources for the suitable processing of thermoplastic and thermoset polymers [25,26], rapid curing of epoxy resins [27], and many other applications where high temperatures are required.

Some of these investigations $[19,23,28]$ refer to a wide number of MNP compositions for induction-heating applications. In particular, iron carbide nanoparticles display an exceptionally high heating power under alternating electromagnetic fields [28]. Despite the high heating efficiency of iron carbide MNPs, one of their main limitations lies in the complexity of their synthesis, which makes it difficult to scale up. However, maghemite $\left(\gamma-\mathrm{Fe}_{2} \mathrm{O}_{3}\right)$ nanoparticles combine in an easy and economical synthetic procedure with high magnetic moments, and it is well established that they are able to generate thermal energy under alternating magnetic fields. Nickel- and cobalt-reduced metal nanoparticles also show suitable magnetic properties (Table 1), but little information is available in the literature regarding their efficiency as magnetic heating agents. Due to the difficulty of stabilizing metallic MNPs, most of the literature refers to their oxides, alloys, or functionalized forms [29-34].

Table 1. Saturation magnetization (Ms) and Curie Temperature for various materials [35].

\begin{tabular}{|c|c|c|c|}
\hline \multirow{2}{*}{ Material } & \multicolumn{2}{|c|}{$\begin{array}{c}\mathrm{Ms} \\
(\mathrm{emu} / \mathrm{g})\end{array}$} & \multirow{2}{*}{$\begin{array}{l}\text { Curie Temperature } \\
\left({ }^{\circ} \mathrm{C}\right)\end{array}$} \\
\hline & $0 \mathrm{~K}$ & $293 \mathrm{~K}$ & \\
\hline $\mathrm{Fe}$ & 221.9 & 218.0 & 770 \\
\hline $\mathrm{Co}$ & 162.5 & 161 & 1131 \\
\hline $\mathrm{Ni}$ & 57.5 & 54.4 & 358 \\
\hline$\gamma-\mathrm{Fe}_{2} \mathrm{O}_{3}$ & 83.5 & 76 & Unstable \\
\hline $\mathrm{Fe}_{3} \mathrm{O}_{4}$ & 98.0 & 92 & 585 \\
\hline
\end{tabular}


In order to determine the potential application of $\gamma-\mathrm{Fe}_{2} \mathrm{O}_{3}$ nanoparticle-impregnated H-USY zeolites for catalytic reactions promoted by acid catalyst under electromagnetic fields, their heating efficiency was previously investigated [36].

In this work, we extended our previous studies to other MNPs, single or combined with $\gamma-\mathrm{Fe}_{2} \mathrm{O}_{3}$, with the aim of introducing new metal centers that may combine catalytic and ferromagnetic properties for potential applications in the catalytic conversion of highdensity polyethylene (HDPE) under hydrogen atmosphere (hydrocracking). Since Ni and Co metallic nanoparticles are commonly used in hydrocracking catalysts, they were selected for this study. It is also worth mentioning that, due to the reductive conditions used in hydrocracking, the reduction of $\gamma-\mathrm{Fe}_{2} \mathrm{O}_{3}$ to metallic iron would be expected to lead to a greater heating efficiency.

Therefore, H-USY zeolite was impregnated with three different MNPs: nickel, cobalt, maghemite and their combinations and then subjected to electromagnetic fields in order to determine the efficiency of the heating induction, the possibility of synergic effects, and the potential of the resulting MNP-derived catalysts for HDPE conversion under hydrogen atmosphere. Induction heating assays were used to compare the heating efficiencies of the different MNP-impregnated zeolites. Experimental parameters involved in the heating capability of these systems such as magnetic field, amplitude, and frequency were systematically investigated. Moreover, preliminary evaluation of the catalytic performance of the MNP-based zeolites was also carried out through thermogravimetric analysis.

\section{Materials and Methods}

\subsection{Materials}

The commercial H-USY zeolite with a Si / Al ratio of 40 (CBV780) was supplied by Zeolyst in a powder form.

Nickel nitrate hexahydrate $\left(\mathrm{Ni}\left(\mathrm{NO}_{3}\right)_{2} \cdot 6 \mathrm{H}_{2} \mathrm{O}\right.$ (Merck, Darmstadt, Germany, $\left.>99 \%\right)$ and cobalt (II) acetate (Sigma Aldrich, St. Louis, MO, USA, $>99 \%$ ) were used as precursor salts for $\mathrm{Ni}$ and $\mathrm{Co}$, respectively.

Commercial high-density polyethylene in powder form and with no additives (HDPE, $\mathrm{MW}=155,000 \mathrm{~g} / \mathrm{mol} ; \mathrm{D}=5.4 ; \mathrm{d}=0.95 \mathrm{~g} / \mathrm{cm}^{3}$ and $\mathrm{Tm}=140{ }^{\circ} \mathrm{C}$ ) was kindly supplied by Repsol (Sines, Portugal).

\subsection{MNPs Synthesis}

The $\gamma-\mathrm{Fe}_{2} \mathrm{O}_{3}$ MNPs were prepared using the Massart modified coprecipitation method, which allows a large quantity of material to be obtained in a cheap way [37]. Briefly, $12 \mathrm{~nm}$ $\gamma$ - $\mathrm{Fe}_{2} \mathrm{O}_{3}$ nanoparticles were prepared by mixing $0.09 \mathrm{~mol}$ of iron (III) chloride 6-hydrate and $0.054 \mathrm{~mol}$ of iron (II) chloride 4-hydrate in a total volume of $488 \mathrm{~mL}$ of distilled water. This solution was added slowly $(0.2 \mathrm{~mL} / \mathrm{s})$ into $75 \mathrm{~mL}$ of a base solution $\left(\mathrm{NH}_{4} \mathrm{OH}\right.$ $25 \%$ ) under constant magnetic stirring. The mixture was heated to $90{ }^{\circ} \mathrm{C}$ and left at this temperature for $1 \mathrm{~h}$. Next, the black product $\left(\mathrm{Fe}_{3} \mathrm{O}_{4}\right)$ was washed several times, by magnetic decantation with distilled water to get rid of the supernatant.

For the oxidation of $\mathrm{Fe}_{3} \mathrm{O}_{4}$ into $\gamma-\mathrm{Fe}_{2} \mathrm{O}_{3}, 300 \mathrm{~mL}$ of $\mathrm{HNO}_{3}(2 \mathrm{M})$ was added to the washed nanoparticles and magnetically stirred for $15 \mathrm{~min}$. Then, the supernatant was removed and a $75 \mathrm{~mL}$ aqueous solution of iron (II) nitrate 9-hydrate (1M) and $130 \mathrm{~mL}$ of distilled water were added. The mixture was heated to a boiling temperature for $30 \mathrm{~min}$. The supernatant was again removed by magnetic decantation and $300 \mathrm{~mL}$ of $\mathrm{HNO}_{3} 2 \mathrm{M}$ was added and mixed for $15 \mathrm{~min}$. Finally, the obtained $\gamma-\mathrm{Fe}_{2} \mathrm{O}_{3}$ nanoparticles were washed with acetone three times. The acetone was evaporated in a rotary evaporator and the nanoparticles were redispersed in distilled water. This second step allows not only the oxidizing of the nanoparticles but also the dissolving of the smallest nanoparticles and the recrystallizing of the larger ones thereby obtaining a narrower distribution. 


\subsection{MNP-Based Catalysts Preparation}

$\mathrm{H}$-USY zeolites were impregnated and co-impregnated with MNPs $\left(\mathrm{Ni}, \mathrm{Co}, \gamma-\mathrm{Fe}_{2} \mathrm{O}_{3}\right.$, $\mathrm{Ni}-\gamma-\mathrm{Fe}_{2} \mathrm{O}_{3}$, and $\mathrm{Co}-\gamma-\mathrm{Fe}_{2} \mathrm{O}_{3}$ ), using the incipient wetness impregnation method in order to obtain the corresponding MNP-based catalysts.

For mono-, Ni-, $\mathrm{Co}-$ and $\gamma$-Fe2O3-impregnated catalysts, a $1.7 \mathrm{~mL}$ aqueous solution of $\mathrm{Ni}\left(\mathrm{NO}_{3}\right)_{2} \cdot 6 \mathrm{H}_{2} \mathrm{O}(\mathrm{C}=155 \mathrm{~g} / \mathrm{L}),\left(\mathrm{CH}_{3} \mathrm{CO}_{2}\right)_{2} \mathrm{Co}(\mathrm{C}=132 \mathrm{~g} / \mathrm{L})$ and $\gamma-\mathrm{Fe} 2 \mathrm{O} 3\left(\mathrm{C}_{\mathrm{Fe}}=72.2 \mathrm{~g} / \mathrm{L}\right)$ was added, respectively, drop by drop to the H-USY(40) zeolite. The samples were air-dried at $80{ }^{\circ} \mathrm{C}$ for $24 \mathrm{~h}$, and posteriorly calcined under airflow $\left(4 \mathrm{~L} \cdot \mathrm{h}^{-1} \cdot \mathrm{g}^{-1}\right)$ at $500{ }^{\circ} \mathrm{C}$. The catalysts preactivation was performed in a glass reactor under hydrogen flow $\left(4 \mathrm{~L} \cdot \mathrm{h}^{-1} \cdot \mathrm{g}^{-1}\right)$ at $500{ }^{\circ} \mathrm{C}$ for $2 \mathrm{~h}$. These last two steps were not performed for $\gamma-\mathrm{Fe}_{2} \mathrm{O}_{3} / \mathrm{H}$-USY(40) in order to avoid the transformation of maghemite into hematite.

For the co-impregnated zeolites $\left(\mathrm{Ni}-\gamma-\mathrm{Fe}_{2} \mathrm{O}_{3}\right.$ and $\left.\mathrm{Co}-\gamma-\mathrm{Fe}_{2} \mathrm{O}_{3}\right)$, the Ni and Co were impregnated first and then the $\gamma-\mathrm{Fe}_{2} \mathrm{O}_{3}$. In this case, $1.7 \mathrm{~mL}$ of Ni(NO$)_{2} \cdot 6 \mathrm{H}_{2} \mathrm{O}(\mathrm{C}=75.5 \mathrm{~g} / \mathrm{L})$ or $\left(\mathrm{CH}_{3} \mathrm{CO}_{2}\right)_{2} \mathrm{Co}(\mathrm{C}=64.4 \mathrm{~g} / \mathrm{L})$ aqueous solution was added to the H-USY(40) zeolite. Then, the impregnated samples were air dried, calcined and pre-activated under the abovementioned conditions. The mono-impregnated Ni/H-USY(40) and Co/H-USY(40) were further co-impregnated through the addition of a $1.7 \mathrm{~mL}$ aqueous solution of $\gamma-\mathrm{Fe}_{2} \mathrm{O}_{3}$ $\left(\mathrm{C}_{\mathrm{Fe}}=35.1 \mathrm{~g} / \mathrm{L}\right)$ and dried at $80{ }^{\circ} \mathrm{C}$ for $24 \mathrm{~h}$.

All materials were prepared with a total metal content of $5 \mathrm{wt} . \%$.

\subsection{HDPE Films Preparation}

The HDPE was mechanically mixed with MNP-based catalysts in a polymer-to-catalyst mass ratio of 7.5/2.5. The mixture was processed into films by compression molding in a Specac hydraulic press (Specac, UK) at $140{ }^{\circ} \mathrm{C}$ for $2 \mathrm{~min}$ without pressure and then for 3 min at 3 ton.

\subsection{MNP-Based Cataysts Characterization}

Textural properties of the prepared catalysts were evaluated from nitrogen adsorptiondesorption isotherms obtained at $-196{ }^{\circ} \mathrm{C}$ using an Autosorb IQ apparatus from Quantachrome (Boynton Beach, FL, USA) Prior to adsorption, the samples were heated under vacuum at $90{ }^{\circ} \mathrm{C}$ for $1 \mathrm{~h}$ and then at $350{ }^{\circ} \mathrm{C}$ for $5 \mathrm{~h}$. The t-plot method was used for the determination of the external surface area $\left(\mathrm{S}_{\mathrm{ext}}\right)$ and for the microporous volume $\left(\mathrm{V}_{\text {micro }}\right)$. The total pore volume $\left(\mathrm{V}_{\text {total }}\right)$ was calculated from the volume of adsorbed $\mathrm{N}_{2}$, at a relative pressure $\left(\mathrm{P} / \mathrm{P}_{\mathrm{o}}\right)$ of 0.95 . The mesoporous volume $\left(\mathrm{V}_{\text {meso }}\right)$ was calculated by the difference between $V_{\text {total }}$ and $V_{\text {micro }}$.

A transmission electron microscope (TEM) JEOL-JEM 2100F (JEOL, Tokyo, Japan) operating at $200 \mathrm{keV}$, was used to study the morphology, particle size, and distribution of the nanoparticles in the H-USY(40) zeolite.

The Powder X-ray diffraction (PXRD) analysis was performed in a Bruker AXS Advance D8 diffractometer (Billerica, MA, USA) equipped with a 1D detector (SSD 160) and operating at $30 \mathrm{~mA}$ and $40 \mathrm{kV}$. A Ni filter, and a radiation source of $\mathrm{CuK} \alpha(\lambda=1.5406 \mathrm{~nm})$ was used and a scanning range from 5 to $80^{\circ}(2 \theta)$, with a step of $0.03^{\circ} / 2 \mathrm{~s}$ was defined.

\subsection{Thermogravimetric Experiments}

The HDPE degradation experiments over distinct catalytic systems were carried out in a Setaram TGA 92-16.18 equipment under $\mathrm{H}_{2}$ atmosphere a flow rate of $30 \mathrm{~mL} / \mathrm{min}$. The temperature was varied from 20 to $700{ }^{\circ} \mathrm{C}$, at a rate of $10^{\circ} \mathrm{C} / \mathrm{min}$. A nitrogen purge was performed before each experiment, to avoid the presence of oxygen.

\subsection{Induction Heating Assays}

Heating properties were measured with a commercial Magnetherm 1.5 (Nanotherics) device (Nanotherics, Warrington, UK). The system is composed of a 17-turn coil with 5 different capacitors, which allows working with different resonance frequencies and studying the effect of the magnetic field and the frequency in the heating release of the 
nanoparticles. The coil temperature was maintained at $16^{\circ} \mathrm{C}$ with a LAUDA Alpha RA12 peristaltic device (Lauda Dr. R. Wobser GMBH \& Co. KG, Lauda-Königshofen, Germany). The temperature increase of the nanoparticle-impregnated zeolite was measured with a thermographic camera FLIR E53 (FLIR ${ }^{\circledR}$ Systems, Inc., Wilsonville, OR, USA), field of vision $24^{\circ} \times 18^{\circ}$ Lens, $(240 \times 180$ pixels resolution $)$ and registered in the computer. Once the thermal stability was reached and before turning the magnetic field on, temperature was registered for $30 \mathrm{~s}$ to obtain the baseline, afterwards the field was switched on. The slope of the heating curve was calculated for the first $30-50 \mathrm{~s}$ after the field was turned on at the maximum field for each frequency.

\section{Results and Discussion}

\subsection{Catalyst Characterization}

The incorporation of a Ni metal source with a zeolite material is a very common procedure in the literature, resulting generally in well-dispersed Ni particles in the supports [38]. Nevertheless, the incorporation of $\gamma-\mathrm{Fe}_{2} \mathrm{O}_{3}$ in zeolite is a less studied topic [36]. Figure 1a displays TEM images of the nanoparticles along with their size distribution fitted to a lognormal distribution; the inset shows the histogram of around 200 nanoparticles exhibiting a mean particle size of $\mathrm{d}=11.7 \mathrm{~nm}$ and a polydispersity degree (standard deviation/mean size) $\sigma=0.2$, as expected [37]. Figure $1 \mathrm{~b}$ shows the TEM images of $\gamma$ - $\mathrm{Fe}_{2} \mathrm{O}_{3} / \mathrm{H}$-USY. It can be seen that $\gamma-\mathrm{Fe}_{2} \mathrm{O}_{3}$ nanoparticles are well dispersed in the H-USY(40) zeolite. In addition, the pore structure of this zeolite is clearly visible.
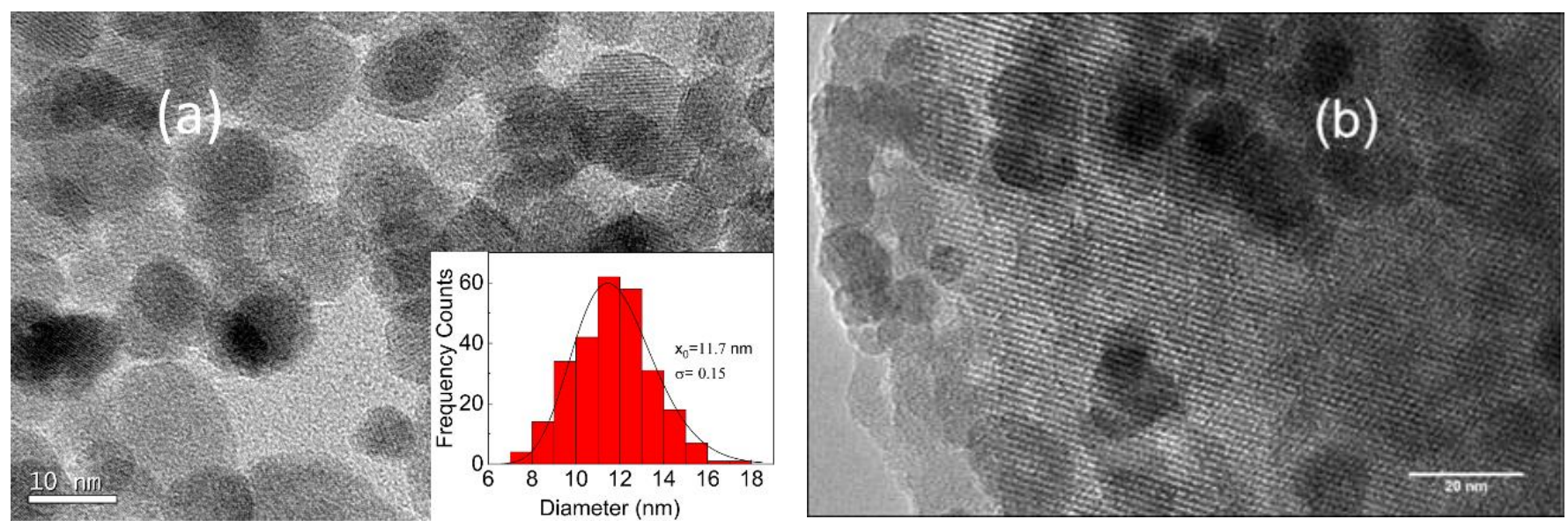

Figure 1. TEM of (a) $\gamma-\mathrm{Fe}_{2} \mathrm{O}_{3}$ nanoparticles with the corresponding histogram and (b) $\gamma-\mathrm{Fe}_{2} \mathrm{O}_{3} / \mathrm{H}-\mathrm{USY}(40)$.

The textural properties of distinct MNP-based catalysts were evaluated from the $\mathrm{N}_{2}$ sorption measurements (Figure 2). According to the IUPAC classification [39], the $\mathrm{H}$ USY(40) zeolite exhibits a combination of a type I and type IV isotherms typical of microporous and mesoporous materials, respectively [40]. According to the literature [41], the appearance of some mesoporosity in H-USY zeolites, which is typical of microporous materials, is related to the post-modification dealumination treatments used for this family of zeolites with distinct $\mathrm{Si} / \mathrm{Al}$ ratios.

Upon the MNP-impregnation process, nonsignificant modifications were observed on the isotherms shape, revealing the preservation of the porous structure. Nevertheless, the external surface area and the microporous and mesoporous volume are reduced for the H-USY(40) zeolites impregnated with $\gamma-\mathrm{Fe}_{2} \mathrm{O}_{3}$ (Table 2), indicating the deposition of MNPs either on the catalyst external surface area or in the of the zeolite pores, corroborating the TEM results $[42,43]$. For the Ni impregnated catalysts the variations on the textural properties are less pronounced. 


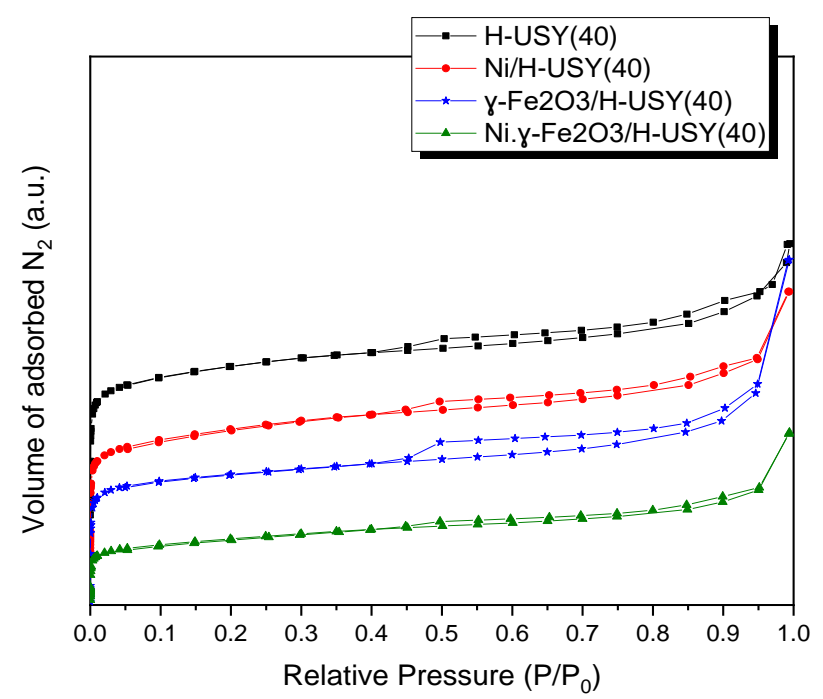

Figure 2. $\mathrm{N}_{2}$ sorption isotherms of parent and MNP-based H-USY(40) zeolites.

Table 2. Textural properties determined by $\mathrm{N}_{2}$ adsorption/desorption for parent H-USY(40) and MNP-based zeolites.

\begin{tabular}{ccccc}
\hline Catalyst Type & $\begin{array}{c}\mathbf{S}_{\text {ext }} \\
\left(\mathbf{m}^{\mathbf{2}} / \mathbf{g}\right)\end{array}$ & $\begin{array}{c}\mathbf{V}_{\text {micro }} \\
\left(\mathbf{c m}^{3} / \mathbf{g}\right)\end{array}$ & $\begin{array}{c}\mathbf{V}_{\text {meso }} \\
\left(\mathbf{c m}^{3} / \mathbf{g}\right)\end{array}$ & $\begin{array}{c}\mathbf{V}_{\text {total }} \\
\left(\mathbf{c m}^{3} / \mathbf{g}\right)\end{array}$ \\
\hline $\mathrm{H}-U S Y(40)$ & 251 & 0.210 & 0.250 & 0.460 \\
$\mathrm{Ni} / \mathrm{H}-\mathrm{USY}(40)$ & 255 & 0.147 & 0.250 & 0.397 \\
$\gamma-\mathrm{Fe}_{2} \mathrm{O}_{3} / \mathrm{H}-U S Y(40)$ & 168 & 0.185 & 0.235 & 0.420 \\
$\mathrm{Ni}-\gamma-\mathrm{Fe}_{2} \mathrm{O}_{3} / \mathrm{H}-U S Y(40)$ & 155 & 0.063 & 0.165 & 0.228 \\
\hline
\end{tabular}

The PXRD results of parent and MNP- $\left(\mathrm{Ni}, \gamma-\mathrm{Fe}_{2} \mathrm{O}_{3}\right.$ and $\left.\mathrm{Ni}-\gamma-\mathrm{Fe}_{2} \mathrm{O}_{3}\right)$ based $\mathrm{H}-\mathrm{USY}(40)$ impregnated zeolites are displayed in Figure 3. The data revealed similar PXRD patterns for parent and MNP-impregnated catalysts with peaks at $2 \theta=6.2^{\circ}(110), 12.1^{\circ}(311), 15.9^{\circ}(400)$, $18.9^{\circ}(333), 20.7^{\circ}(440), 27.0^{\circ}$ (642) and $27.5^{\circ}$ (731), typical of faujasite (FAU) structure. This indicates that the structure was not modified after the impregnation procedure thus, corroborating the $\mathrm{N}_{2}$ sorption data. Additional reflections, characteristic of metallic nickel $(\mathrm{Ni})$ and $\gamma-\mathrm{Fe}_{2} \mathrm{O}_{3}$ are detected respectively, at $2 \theta=45^{\circ}$ (111) and $2 \theta=35.6^{\circ}$ (311) and $62.8^{\circ}$ (440). In the case of $\mathrm{Ni}-\gamma-\mathrm{Fe}_{2} \mathrm{O}_{3} / \mathrm{H}-\mathrm{USY}(40)$ sample, no characteristic peaks belonging to $\mathrm{Ni}^{0}$ are detected, probably because a smaller amount of $\mathrm{Ni}$ was used in this catalyst (2.5 wt.\%).

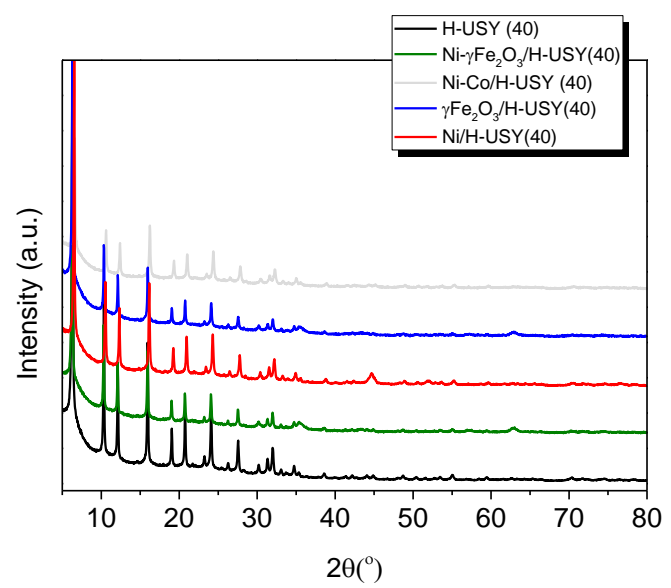

(a)

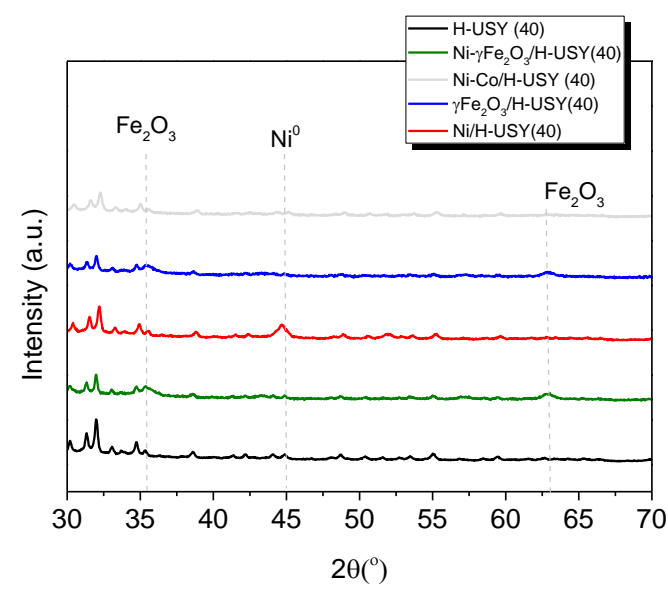

(b)

Figure 3. (a) XRD patterns of parent and MNPs impregnated H-USY(40) zeolites; (b) Magnification. 


\subsection{Degradation Experiments}

TGA is widely used as a tool to assess the potential of distinct catalytic systems to promote the degradation of polymers, especially concerning energy requirements [44,45]. In the present study, the effectiveness of the MNP-catalytic systems for HDPE degradation under reductive conditions was evaluated using TGA. The mass loss and heat-flow profiles are displayed in Figure 4, and the temperatures at which mass loss is 5, 50 and 95\% ( $\mathrm{T}_{5 \%}$, $\mathrm{T}_{50 \%}$ and $\mathrm{T}_{95 \%}$ ) are summarized in Table 3.

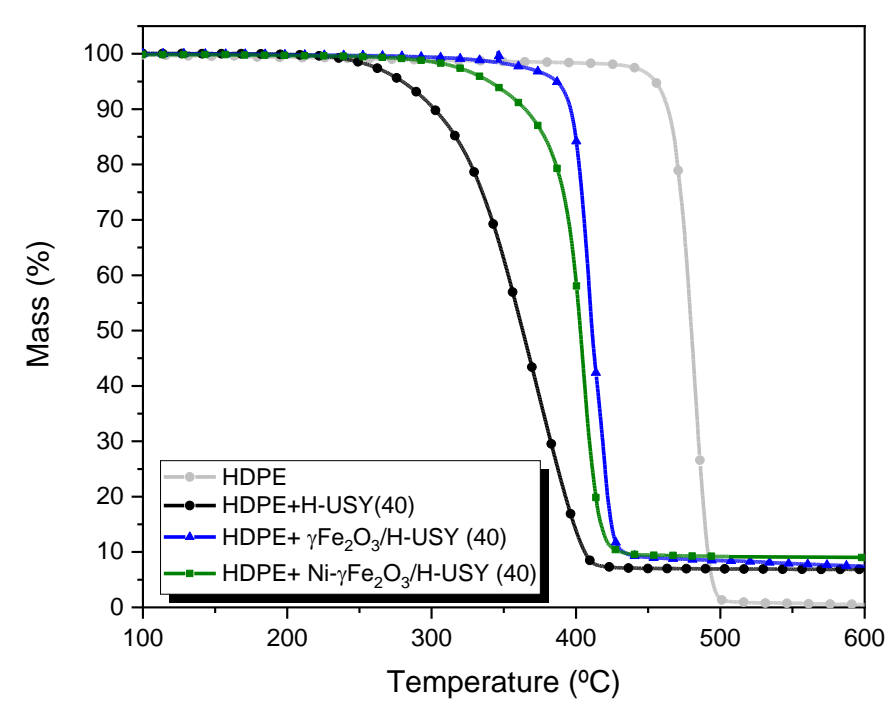

(a)

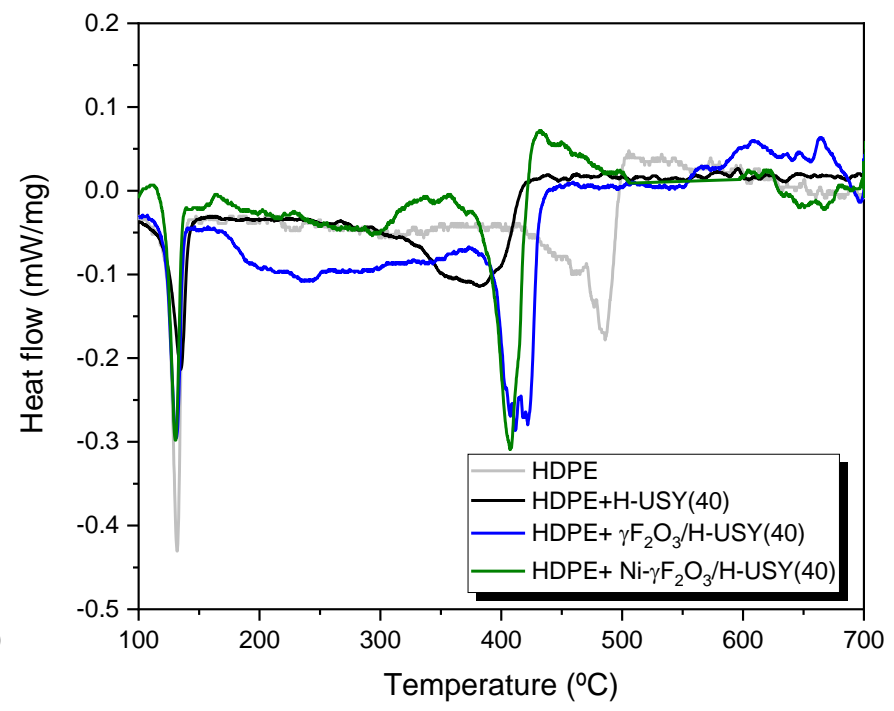

(b)

Figure 4. TGA (a) and heat flows (b) profiles for the catalytic degradation of HDPE under $\mathrm{H}_{2}$ atmosphere over parent and MNPs impregnated H-USY(40) zeolites.

Table 3. Comparison of T5\%, T50\% and T95\% for HDPE degradation on H-USY(15) catalyst at $15 \%$.

\begin{tabular}{cccc}
\hline Sample & $\mathbf{T}_{\mathbf{5 \%}}\left({ }^{\circ} \mathbf{C}\right)$ & $\mathbf{T}_{\mathbf{5 0} \%}\left({ }^{\circ} \mathbf{C}\right)$ & $\mathbf{T}_{\mathbf{9 5 \%}}\left({ }^{\circ} \mathbf{C}\right)$ \\
\hline HDPE & 433 & 478 & 488 \\
$\mathrm{HDPE}+\mathrm{H}-\mathrm{USY}(40)$ & 270 & 357 & 399 \\
$\mathrm{HDPE}+\gamma-\mathrm{Fe}_{2} \mathrm{O}_{3} / \mathrm{H}-\mathrm{USY}(40)$ & 384 & 409 & 425 \\
$\mathrm{HDPE}+\mathrm{Ni} / \gamma-\mathrm{Fe}_{2} \mathrm{O}_{3} / \mathrm{H}-\mathrm{USY}(40)$ & 335 & 401 & 418 \\
\hline
\end{tabular}

The data showed that thermal degradation of HDPE occurred in a single mass-loss step, exhibiting a degradation range between 433 and $488^{\circ} \mathrm{C}$, and corroborates the highenergy consumption associated with HDPE conversion. The addition of a catalyst facilitates HDPE degradation, shifting the degradation profiles to lower temperature values. The highest shift was observed for H-USY(40), which allowed for a diminishment of $184{ }^{\circ} \mathrm{C}$ on $\mathrm{T}_{5 \%}$ when compared to the thermal run.

The introduction of $\gamma-\mathrm{Fe}_{2} \mathrm{O}_{3}$ in the H-USY(40) zeolite resulted in an increase of $\mathrm{T}_{5 \%}$, $\mathrm{T}_{50 \%}$ and $\mathrm{T}_{95 \%}$ relative to the parent zeolite, which may be attributed to a decrease in the accessibility of HDPE macromolecules to the porous zeolite framework. $\mathrm{N}_{2}$ sorption data corroborated this assumption. As already mentioned, a reduction in the textural properties ( $\mathrm{S}_{\text {ext }}, \mathrm{V}_{\text {micro }}, \mathrm{V}_{\text {meso }}$ ) was observed, indicating the depositing of $\gamma-\mathrm{Fe}_{2} \mathrm{O}_{3}$ on the H-USY surface and on the porous structure, thus hindering the access of the polymer to the active centers. Although $\gamma-\mathrm{Fe}_{2} \mathrm{O}_{3}$ is not a suitable metallic center for the hydrocracking process, as it does not improve the degradation process, it is essential for the reduction of energy consumption through a magnetic-induced field.

In turn, the association of $\mathrm{Ni}$ to the previous $\gamma-\mathrm{Fe}_{2} \mathrm{O}_{3} / \mathrm{H}$-USY(40) system leads to a decrease of $\mathrm{T}_{5 \%}$, and to a reduction in the energy requirements of the process. The beneficial 
role of $\mathrm{Ni}$ on hydrocracking reactions was already reported in a previous publication [38]. In contrast to $\gamma-\mathrm{Fe}_{2} \mathrm{O}_{3}, \mathrm{Ni}$ exhibits a good dehydrogenation-hydrogenation ability, which is essential for hydrocracking reactions. Despite the positive effect of $\mathrm{Ni}, \mathrm{T}_{5} \%$ still remains higher than the value observed for the parent zeolite, and further research will be necessary to avoid the loss of the active center's accessibility and to improve the catalytic behavior of MNP-impregnated catalysts.

The heat flow profiles, showed in Figure $4 \mathrm{~b}$ reveal the presence of two distinct endothermic peaks. The first, around $140{ }^{\circ} \mathrm{C}$, is due to the melting of the polymer. The second one corresponds to the degradation of HDPE and, therefore, is accompanied by a mass loss. Unlike the first peak, which appears at the same temperature, the position of the second peak is strongly influenced by the presence or absence of a catalyst and also by the catalyst nature. In this case, the most promising catalytic systems for converting HDPE exhibit the degradation peak at lower temperatures.

Since hydrocracking reactions are performed in a reductive atmosphere, it was also found important to evaluate the stability of mono- and co-impregnated zeolites under these conditions. In a previous study [36] on the stability of parent $\gamma-\mathrm{Fe}_{2} \mathrm{O}_{3} \mathrm{MNPs}$ and $\gamma-\mathrm{Fe}_{2} \mathrm{O}_{3}$ MNPs impregnated in H-USY(40) zeolite under hydrogen atmosphere, it was found that the $\gamma-\mathrm{Fe}_{2} \mathrm{O}_{3}$ nanoparticles exhibited two distinct mass losses: one at $344-444{ }^{\circ} \mathrm{C}$ and the other at $444-634{ }^{\circ} \mathrm{C}$, corresponding respectively, to the transformation of $\gamma-\mathrm{Fe}_{2} \mathrm{O}_{3}$ to $\mathrm{Fe}_{3} \mathrm{O}_{4}$ and its subsequent reduction to metallic Fe. In turn, when $\gamma-\mathrm{Fe}_{2} \mathrm{O}_{3}$ was impregnated in $\mathrm{H}-\mathrm{USY}(40)$ zeolite, a continuous reduction pattern was observed. A similar behavior can be observed for the co-impregnated $\mathrm{Ni}-\gamma-\mathrm{Fe}_{2} \mathrm{O}_{3} / \mathrm{H}-\mathrm{USY}(40)$ zeolite displayed in Figure S1 of SUP INF. As Ni nanoparticles, both in mono- and co-impregnated H-USY(40) zeolite, were already in a reduced form, no further changes were expected to occur under hydrogen atmosphere.

\subsection{Induction Heating Assays}

Taking into account the promising exploratory results obtained for HDPE degradation, the previous MNP-impregnated H-USY systems were subjected to induction heating experiments, and the heating rate of the MNPs supported on the zeolite under radio-frequency fields was evaluated. These tests were also extended to $\mathrm{Co}$ and $\mathrm{Ni}-\mathrm{Co}$-impregnated $\mathrm{H}-$ USY(40) zeolites in order to evaluate possible synergetic effects in the magnetic properties. Five different combinations of three nanoparticles with high values of magnetic susceptibility $\left(\gamma-\mathrm{Fe}_{2} \mathrm{O}_{3}, \mathrm{Ni}\right.$ and $\left.\mathrm{Co}\right)$ were analyzed.

The experiments were performed in an air atmosphere, but more positive results are expected under hydrogen atmosphere (used in the hydrocracking process), where maghemite is reduced to metallic iron with a higher saturation magnetization (Table 1). Consequently, higher temperatures will be reached.

\subsubsection{Induction Heating on Impregnated H-USY(40)}

H-USY(40) zeolites impregnated with MNPs (powder) were manufactured in pellets with a hydraulic press. The concentration of the MNPs with respect to the mass of zeolite is $5 \%$ for most samples. In the case of $\mathrm{Ni}-\gamma-\mathrm{Fe}_{2} \mathrm{O}_{3}$ and Ni-Co mixtures, $2.5 \%$ of each metal was used to reach the total concentration (5\%) required.

According to previous work [46], the heating efficiency was evaluated by means of the Specific Absorption Rate (SAR) as

$$
S A R=\frac{C z}{[F e]} \frac{\Delta T}{\Delta t}
$$

where $C z$ is the heat capacity of zeolite (unknown), $[\mathrm{Fe}]$ is the iron mass concentration, $\Delta T$ is the temperature increment, $\Delta t$ is the time increase and $\Delta T / \Delta t$ is the initial slope of the heating curve.

SAR calculation requires the knowledge of the heating capacity of the zeolite (Equation (1)), which is unknown in this case. Assuming that the heating capacity $(C z)$ of the H-USY(40) 
zeolite is the same for all the samples, the initial slope, $\Delta T / \Delta t$, of the heating curve was used to calculate the heating rate per Fe unit mass of each sample, $\Delta T / \Delta t /[\mathrm{Fe}]$.

The heating curves for all the samples at three different frequencies 112, 627 and $990 \mathrm{kHz}$ (low, medium and high) are displayed in Figure S2 in SUP INF. The samples showing a significant heating rate are those impregnated with $\gamma-\mathrm{Fe}_{2} \mathrm{O}_{3}$ and $\mathrm{Ni}-\gamma-\mathrm{Fe}_{2} \mathrm{O}_{3}$ whereas those, containing $\mathrm{Ni}$ and $\mathrm{Ni}-\mathrm{Co}$ exhibited a negligible temperature increase, probably due to the oxidation suffered by $\mathrm{Ni}$ and $\mathrm{Co}$ metals under air atmosphere.

In Table 4 it is shown the heating rate/unit mass obtained for H-USY(40) impregnated with $\gamma-\mathrm{Fe}_{2} \mathrm{O}_{3}$ and $\mathrm{Ni}-\gamma-\mathrm{Fe}_{2} \mathrm{O}_{3}$ at 10 different frequencies. Based on these results it was decided to perform induction heating tests at the same frequency: $526 \mathrm{kHz}$ and 100 Oe for all samples. Although the $\Delta T / \Delta t) /[\mathrm{Fe}]$ value obtained for $\mathrm{Ni}-\gamma-\mathrm{Fe}_{2} \mathrm{O}_{3}$ system was slightly higher at $112 \mathrm{kHz}$ than at $526 \mathrm{kHz}$ the difference is rather small. The data in this Table also suggest a positive synergistic effect between $\mathrm{Ni}$ and $\gamma-\mathrm{Fe}_{2} \mathrm{O}_{3}$ since the heating rate per Fe mass increases $50 \%$ under the presence of $\mathrm{Ni}$.

Table 4. Slope, $(\Delta T / \Delta t) / \mathrm{Fe}$, of the induction heating curve for $\mathrm{H}$-USY(40) impregnated with $\gamma-\mathrm{Fe}_{2} \mathrm{O}_{3}$ and $\mathrm{Ni}-\gamma-\mathrm{Fe}_{2} \mathrm{O}_{3}$ zeolites.

\begin{tabular}{|c|c|c|c|}
\hline $\begin{array}{c}\text { Frequency } \\
\quad(\mathbf{k H z})\end{array}$ & $\begin{array}{l}\text { Field } \\
\text { (Oe) }\end{array}$ & $\begin{array}{c}\gamma-\mathrm{Fe}_{2} \mathrm{O}_{3} \\
(\Delta T / \Delta t) /[\mathrm{Fe}] \\
(\mathrm{K} / \mathrm{s})\end{array}$ & $\begin{array}{c}\mathrm{Ni}-\gamma-\mathrm{Fe}_{2} \mathrm{O}_{3} \\
(\Delta T / \Delta t) /[\mathrm{Fe}] \\
(\mathrm{K} / \mathrm{s})\end{array}$ \\
\hline 112 & 172 & 14.57 & 38.29 \\
\hline 165 & 133 & 8.57 & 22.86 \\
\hline 177 & 124 & 12.57 & 21.14 \\
\hline 263 & 73 & 18.29 & 28.00 \\
\hline 331 & 60 & 22.29 & 34.86 \\
\hline 468 & 73 & 11.71 & 20.00 \\
\hline 526 & 94 & 23.43 & 35.43 \\
\hline 625 & 50 & 6.00 & 12.00 \\
\hline 740 & 35 & 6.57 & 9.14 \\
\hline 990 & 32 & 4.00 & 6.86 \\
\hline
\end{tabular}

Figure 5 shows the induction heating curves for zeolite H-USY(40) impregnated with $\gamma-\mathrm{Fe}_{2} \mathrm{O}_{3}$ (blue), $\mathrm{Ni}$ (red) and the $\mathrm{Ni}-\gamma-\mathrm{Fe}_{2} \mathrm{O}_{3}$ (green) MNPs at 5\%, at $526 \mathrm{kHz}$ and 100 Oe. A temperature increase about $75{ }^{\circ} \mathrm{C}$ in $800 \mathrm{~s}$ is observed for the $\gamma-\mathrm{Fe}_{2} \mathrm{O}_{3}$-impregnated system and $70{ }^{\circ} \mathrm{C}$ for the $\mathrm{Ni}-\gamma-\mathrm{Fe}_{2} \mathrm{O}_{3}$ one. The results obtained for the $\gamma-\mathrm{Fe}_{2} \mathrm{O}_{3}$-impregnated zeolite were quite similar to those referred to in a previous publication [36].

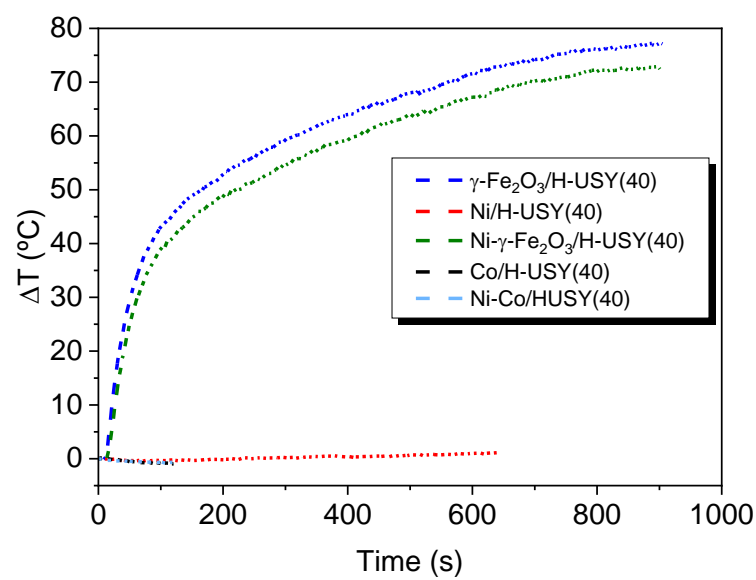

Figure 5. Induction heating curves $(526 \mathrm{kHz})$ of $\mathrm{H}-\mathrm{USY}(40)$ impregnated with $\gamma-\mathrm{Fe}_{2} \mathrm{O}_{3}$ (Dark blue), $\mathrm{Ni}-\gamma-\mathrm{Fe}_{2} \mathrm{O}_{3}$ (Green), $\mathrm{Ni}$ (Red), Ni-Co mixture (Light blue) and Co (Black).

Even though the thermographic camera detected a global temperature increase of approximately $75^{\circ} \mathrm{C}$, it is probable that the local temperature reached at the MNPs surface 
was much higher because they emitted heat to the rest of the sample and the polymer used had a low thermal conductivity.

\subsubsection{Heating Induction on HDPE and Reinforced Catalysts Films}

Additional induction-heating experiments were performed over HDPE-zeolite-MNP films in order to determine the respective heating rate under radio-frequency fields. Films containing $25 \mathrm{wt}$.\% of a catalyst were subjected to a systematic frequency sweep to find the maximum degree of induction heating on each film (see supporting information Figure S2a-c). Similarly to the previous results, only the films containing H-USY impregnated with $\gamma-\mathrm{Fe}_{2} \mathrm{O}_{3}$ and $\mathrm{Ni}-\gamma-\mathrm{Fe}_{2} \mathrm{O}_{3}$ at $526 \mathrm{kHz}$ showed a significant temperature increase.

Figure 6 displays the temperature variation as a function of time for the HDPE-zeoliteMNPs films at $526 \mathrm{kHz}: \gamma-\mathrm{Fe}_{2} \mathrm{O}_{3}$ is shown in red and $\mathrm{Ni}-\gamma-\mathrm{Fe}_{2} \mathrm{O}_{3}$ in blue. A smaller temperature increment was observed for HDPE films compared to the parent MNP-impregnated zeolites. This was due to a decrease in the concentration of nanoparticles in the HDPE films by a factor of four.

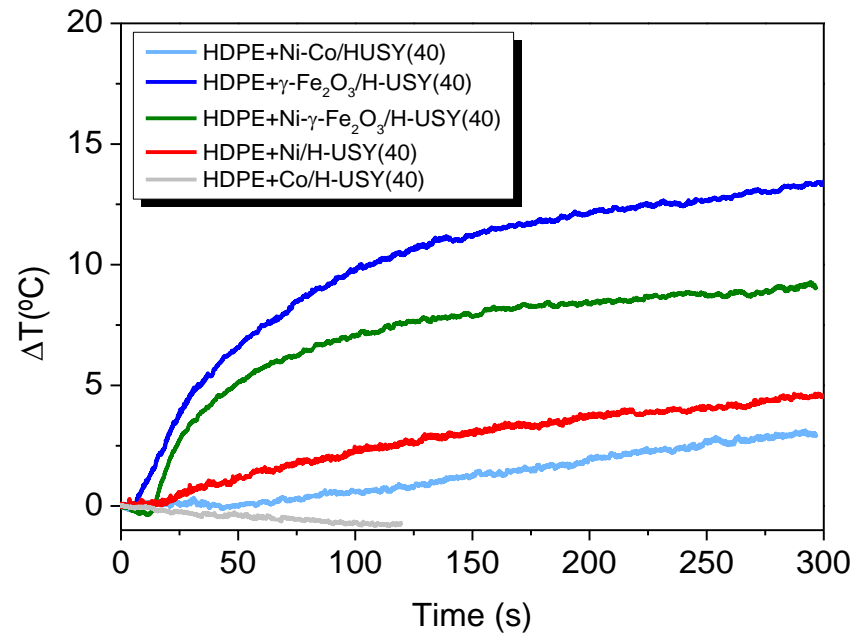

Figure 6. Temperature increment curves $(526 \mathrm{kHz})$ for HDPE films containing H-USY(40) impregnated with: $\gamma-\mathrm{Fe}_{2} \mathrm{O}_{3}$ (Dark blue), $\mathrm{Ni}-\gamma-\mathrm{Fe}_{2} \mathrm{O}_{3}$ (Green), $\mathrm{Ni}$ (Red), Ni-Co mixture (Light Blue) and Co (Grey) over time.

Table 5 displays the variation of the heating rate/unit mass with frequency for the HDPE films. The optimal frequency at which maximum degree of induction heating occurs is the same as observed for the impregnated zeolite systems in the previous section.

Table 5. Slope $(\Delta T / \Delta t) /$ Fe of the induction heating curve for HDPE films containing H-USY(40) impregnated with $\gamma-\mathrm{Fe}_{2} \mathrm{O}_{3}$ and $\mathrm{Ni}-\gamma-\mathrm{Fe}_{2} \mathrm{O}_{3}$.

\begin{tabular}{|c|c|c|c|}
\hline $\begin{array}{l}\text { Frequency } \\
\quad(\mathbf{k H z})\end{array}$ & $\begin{array}{l}\text { Field } \\
\text { (Oe) }\end{array}$ & $\begin{array}{c}\gamma-\mathrm{Fe}_{2} \mathrm{O}_{3} \\
(\Delta T / \Delta t) /[\mathrm{Fe}] \\
(\mathrm{K} / \mathrm{s})\end{array}$ & $\begin{array}{c}\mathrm{Ni}-\gamma-\mathrm{Fe}_{2} \mathrm{O}_{3} \\
(\Delta T / \Delta t) /[\mathrm{Fe}] \\
(\mathrm{K} / \mathrm{s})\end{array}$ \\
\hline 112 & 172 & 12.57 & 16.00 \\
\hline 165 & 133 & 5.71 & 9.14 \\
\hline 177 & 124 & 8.00 & 9.14 \\
\hline 263 & 73 & 10.29 & 18.29 \\
\hline 331 & 60 & 13.71 & 20.57 \\
\hline 468 & 73 & 5.71 & 9.14 \\
\hline 526 & 94 & 14.86 & 29.71 \\
\hline 625 & 50 & 2.29 & 2.29 \\
\hline 740 & 35 & 1.14 & 4.57 \\
\hline 990 & 32 & 1.14 & 0.00 \\
\hline
\end{tabular}


In addition, as shown in Tables 4 and 5, the temperature increase per mass concentration $(\Delta T / \Delta t) /[\mathrm{Fe}]$ for $\gamma-\mathrm{Fe}_{2} \mathrm{O}_{3}$ - and $\mathrm{Ni}-\gamma-\mathrm{Fe}_{2} \mathrm{O}_{3}$-impregnated $\mathrm{H}$-USY $(40)$ zeolites and for the corresponding HDPE-zeolite-MNP films is very similar and shows its maximum at $526 \mathrm{kHz}$. These results suggest that the film preparation does not affect the heating efficiency of nanoparticles.

The $\mathrm{Ni}-\gamma-\mathrm{Fe}_{2} \mathrm{O}_{3}$ and $\gamma-\mathrm{Fe}_{2} \mathrm{O}_{3}$ based systems show a considerable temperature increase per Fe mass of 29.71 and $14.86 \mathrm{~K} / \mathrm{s}$ respectively. Since the amount of magnetic Fe cations in $\mathrm{Ni}-\gamma-\mathrm{Fe}_{2} \mathrm{O}_{3}$ is the half of $\gamma-\mathrm{Fe}_{2} \mathrm{O}_{3}$, and Ni nanoparticles do not show any temperature increase, which suggests an extra contribution to the heating, thus corroborating the synergistic effect of $\mathrm{Ni}$ and $\gamma-\mathrm{Fe}_{2} \mathrm{O}_{3}$ as proposed in the previous section.

\section{Conclusions}

In this work, we investigated the effect of adding several types of MNPs (Ni, Co and $\gamma-\mathrm{Fe}_{2} \mathrm{O}_{3}$ ) to a zeolite catalyst to determine the local heating ability of these MNPs and the degradation of HDPE under hydrogen atmosphere promoted by these MNP-derived catalysts.

The combination of catalytic and magnetic properties in these new materials offered one interesting advantage: the instantaneous transfer of heat directly to the active sites of the catalyst so that the heat source--the MNPs subjected to alternating magnetic fieldscame from inside the zeolite, which should minimize the energy loss of conventional heating systems with external energy suppliers.

The results shown here demonstrated that under an electromagnetic field (work frequency of $526 \mathrm{kHz}$ and air atmosphere) the combination of $\mathrm{Ni}$ and $\gamma-\mathrm{Fe}_{2} \mathrm{O}_{3}$ with the HUSY(40) zeolite permitted the rapid increase of the local temperature up to $80^{\circ} \mathrm{C}$. Moreover, the effectiveness of the heating induction process was expected to be improved under the hydrogen atmosphere used in the hydrocracking process because of the reduction of maghemite to metallic iron with a higher saturation magnetization.

This preliminary investigation can be taken as a proof of concept and a first indication of the potential of MNP-derived zeolite catalysts for use as a complimentary heating source for the catalytic conversion of HDPE under $\mathrm{H}_{2}$ atmosphere. The approach developed here may provide an interesting auxiliary route to reducing the energetic requirements of catalytic processes and the environmental impact of plastic waste, which is in line with EU policy.

Further research, both regarding the development of more efficient magnetic nanoparticles and more effective catalysts, is necessary for a full assessment of MNP-derived catalyst abilities. The application of this concept to other high energy-consuming catalytic processes is another possibility.

\section{Patents}

This section is not mandatory but may be added if there are patents resulting from the work reported in this manuscript.

Supplementary Materials: The following are available online at https://www.mdpi.com/1996 $-1944 / 14 / 4 / 1029 / s 1$. Figure S1: TGA of Ni and Ni- $\gamma$-Fe2O3 impregnated H-USY(40) zeolites, under hydrogen atmosphere; Figure S2a: Heating curves of all the samples: films with HDPE (continuous lines) and pellets (dashed lines) at $112 \mathrm{kHz}$; Figure S2b: Heating curves of all the samples (films and pellets) at $627 \mathrm{kHz}$; Figure S2c: Heating curves of all the samples (films and pellets) at $990 \mathrm{kHz}$.

Author Contributions: Conceptualization: M.M. (Marta Muñoz), M.d.R.R., and P.d.l.P.; methodology: M.M. (Marta Muñoz), M.d.R.R., P.d.l.P., M.M. (Marta Multigner), and J.M.A.; validation: M.M. (Marta Muñoz) and M.d.R.R.; formal analysis: C.S.C., I.M., J.M.A., J.M.S., and B.T.; investigation: C.S.C., I.M., J.M.A., J.M.S., and M.M. (Marta Multigner); resources: M.M. (Marta Muñoz), P.d.1.P., and J.R.; data curation: C.S.C., I.M., and M.M. (Marta Multigner); writing-review and editing: M.M. (Marta Muñoz), M.d.R.R., P.d.l.P., C.S.C., and M.M. (Marta Multigner); visualization: M.M. (Marta Muñoz), M.d.R.R. and C.S.C.; supervision: M.M. (Marta Muñoz), M.d.R.R., and P.d.l.P.; project 
administration: M.M. (Marta Muñoz); funding acquisition: M.M. (Marta Muñoz), M.d.R.R., J.R., B.T. and P.d.l.P. All authors have read and agreed to the published version of the manuscript.

Funding: This research was funded by Mineco Projects MAT2015-66334-C3-3-R and RTI2018-095856B-C21. Comunidad de Madrid Project Aditimat- CM-S2018/NMT-4411, P2018/NMT-4321 and MAT2015-63974-C4 and Ayudas a la Movilidad PDI URJC 2018 and PDI URJC 2019.

Data Availability Statement: Data available in a publicly accessible repository.

Acknowledgments: The authors also acknowledge the technical support given by Fernando Giacomone financed by Spanish Ministry of Science and Innovation, PTA2015-10497-I and the student Angela Bermejo.

Conflicts of Interest: The authors declare no conflict of interest. The funders had no role in the design of the study; in the collection, analyses or interpretation of data; in the writing of the manuscript or in the decision to publish the results.

$\begin{array}{ll}\text { Abbreviations } \\ \text { Cz } & \text { Heat capacity } \\ \text { d } & \text { Diameter } \\ \text { D } & \text { Molecular weight dispersion } \\ \text { FTIR } & \text { Fourier transform infrared spectroscopy } \\ \text { FCC } & \text { Fluid catalytic cracking } \\ \text { HDPE } & \text { High density polyethylene } \\ \text { IMA } & \text { Institute of Magnetism Applied } \\ \text { IST } & \text { Institute Superior Technique } \\ \text { MNC } & \text { Magnetic nanoparticle concentration } \\ \text { MNP } & \text { Magnetic nanoparticle } \\ \text { Ms } & \text { Saturation magnetization } \\ \text { MW } & \text { Molecular weight } \\ \text { MWD } & \text { Molecular weight distribution } \\ \text { SAR } & \text { Specific absorption rate } \\ \text { SEM } & \text { Scanning electron microscopy } \\ \text { Sext } & \text { External surface area } \\ \text { TEM } & \text { Transmission electron microscopy } \\ \text { TGA } & \text { Thermogravimetric analysis } \\ \text { Tm } & \text { Melting temperature } \\ \text { UCM } & \text { University Complutense of Madrid } \\ \text { Vmeso } & \text { Mesoporous volume } \\ \text { Vmicro } & \text { Microporous volume } \\ \text { Vtotal } & \text { Total pore volume } \\ \text { W } & \text { Weight } \\ \text { PXRD } & \text { Powder X-Ray diffraction } \\ & \end{array}$

\section{References}

1. PlasticsEurope. Plastics—The Facts 2019; PlasticsEurope: Brussels, Belgium, 2019.

2. Siddiqui, M.N.; Redhwi, H.H. Catalytic coprocessing of waste plastics and petroleum residue into liquid fuel oils. J. Anal. Appl. Pyrolysis 2009, 86, 141-147. [CrossRef]

3. Schmidt, C.; Krauth, T.; Wagner, S. Correction to export of plastic debris by rivers into the sea. Environ. Sci. Technol. 2018, 52, 927. [CrossRef]

4. Munir, D.; Abdullah; Piepenbreier, F.; Usman, M.R. Hydrocracking of a plastic mixture over various micro-mesoporous composite zeolites. Powder Technol. 2017, 316, 542-550. [CrossRef]

5. Munir, D.; Irfan, M.F.; Usman, M.R. Hydrocracking of virgin and waste plastics: A detailed review. Renew. Sustain. Energy Rev. 2018, 90, 490-515. [CrossRef]

6. Mendes, P.S.F.; Silva, J.M.; Ribeiro, M.F.; Bouchy, C.; Daudin, A. Quantification of the available acid sites in the hydrocracking of nitrogen-containing feedstocks over USY shaped NiMo-catalysts. J. Ind. Eng. Chem. 2019, 71, 167-176. [CrossRef]

7. Ding, W.; Liang, J.; Anderson, L.L. Hydrocracking and hydroisomerization of high-density polyethylene and waste plastic over zeolite and silica-Alumina-supported Ni and Ni-Mo sulfides. Energy Fuels 1997, 11, 1219-1223. [CrossRef] 
8. Sriningsih, W.; Saerodji, M.G.; Trisunaryanti, W.; Triyono; Armunanto, R.; Falah, I.I. Fuel Production from LDPE Plastic Waste over Natural Zeolite Supported Ni, Ni-Mo, Co and Co-Mo Metals. Procedia Environ. Sci. 2014, 20, 215-224. [CrossRef]

9. Galadima, A.; Muraza, O. Hydrocracking catalysts based on hierarchical zeolites: A recent progress. J. Ind. Eng. Chem. 2018, 61, 265-280. [CrossRef]

10. Ali, M.A.; Tatsumi, T.; Masuda, T. Development of heavy oil hydrocracking catalysts using amorphous silica-alumina and zeolites as catalyst supports. Appl. Catal. A Gen. 2002, 233, 77-90. [CrossRef]

11. Ochoa, R.; Van Woert, H.; Lee, W.H.; Subramanian, R.; Kugler, E.; Eklund, P.C. Catalytic degradation of medium density polyethylene over silica-alumina supports. Fuel Process. Technol. 1996, 49, 119-136. [CrossRef]

12. Mosio-Mosiewski, J.; Warzala, M.; Morawski, I.; Dobrzanski, T. High-pressure catalytic and thermal cracking of polyethylene. Fuel Process. Technol. 2007, 88, 359-364. [CrossRef]

13. Escola, J.M.; Aguado, J.; Serrano, D.P.; García, A.; Peral, A.; Briones, L.; Calvo, R.; Fernandez, E. Catalytic hydroreforming of the polyethylene thermal cracking oil over Ni supported hierarchical zeolites and mesostructured aluminosilicates. Appl. Catal. B Environ. 2011, 106, 405-415. [CrossRef]

14. Metecan, I.H.; Ozkan, A.R.; Isler, R.; Yanik, J.; Saglam, M.; Yuksel, M. Naphtha derived from polyolefins. Fuel 2005, 84, 619-628. [CrossRef]

15. Utami, S.; Wijaya, K.; Trisunaryanti, W. Pt-promoted sulfated zirconia as catalyst for hydrocracking of LDPE plastic waste into liquid fuels. Mater. Chem. Phys. 2018, 213, 548-555. [CrossRef]

16. Pan, Z.; Xue, X.; Zhang, C.; Wang, D.; Xie, Y.; Zhang, R. Production of aromatic hydrocarbons by hydro-liquefaction of high-density polyethylene (HDPE) over Ni/HZSM-5. J. Anal. Appl. Pyrolysis 2018, 136, 208-214. [CrossRef]

17. Hauli, L.; Wijaya, K.; Syoufian, A. Hydrocracking of LDPE Plastic Waste into Liquid Fuel over Sulfated Zirconia from a Commercial Zirconia Nanopowder. Orient. J. Chem. 2019, 35, 128-133. [CrossRef]

18. Samperio, J.A. Alternative Catalytic Processes for the Valorization of Plastic Waste to Fuels; Universidad del País Vasco: Basque Country, Spain, 2016.

19. Niether, C.; Faure, S.; Bordet, A.; Deseure, J.; Chatenet, M.; Carrey, J.; Chaudret, B.; Rouet, A. Improved water electrolysis using magnetic heating of FeC-Ni core-shell nanoparticles. Nat. Energy 2018, 1-8. [CrossRef]

20. Zyuzin, M.V.; Cassani, M.; Barthel, M.J.; Gavilan, H.; Silvestri, N.; Escudero, A.; Scarpellini, A.; Lucchesi, F.; Teran, F.J.; Parak, W.J.; et al. Confining Iron Oxide Nanocubes inside Submicrometric Cavities as a Key Strategy to Preserve Magnetic Heat Losses in an Intracellular Environment. ACS Appl. Mater. Interfaces 2019, 11, 41957-41971. [CrossRef]

21. Rubia-Rodríguez, I.; Santana-Otero, A.; Spassov, S.; Tombácz, E.; Johansson, C.; De La Presa, P.; Francisco, J.T.; del Puerto, M.M.; Veintemillas-Verdaguer, S.; Nguyen, T.K.T.; et al. Whither Magnetic Hyperthermia? A Tentative Roadmap. Materials 2021, 14, 706. [CrossRef]

22. Rivas-Murias, B.; Asensio, J.M.; Mille, N.; Rodríguez-González, B.; Fazzini, P.F.; Carrey, J.; Chaudret, B.; Salgueiriño, V. Magnetically Induced CO2 Methanation Using Exchange-Coupled Spinel Ferrites in Cuboctahedron-Shaped Nanocrystals. Angew. Chem. Int. Ed. 2020, 59, 15537-15542. [CrossRef]

23. Bordet, A.; Lacroix, L.M.; Fazzini, P.F.; Carrey, J.; Soulantica, K.; Chaudret, B. Magnetically Induced Continuous CO2Hydrogenation Using Composite Iron Carbide Nanoparticles of Exceptionally High Heating Power. Angew. Chem. Int. Ed. 2016, 55, 15894-15898. [CrossRef]

24. Urraca, J.L.; Cortés-Llanos, B.; Aroca, C.; de la Presa, P.; Pérez, L.; Moreno-Bondi, M.C. Magnetic Field-Induced Polymerization of Molecularly Imprinted Polymers. J. Phys. Chem. C 2018. [CrossRef]

25. Beck, M.M.; Lammel, C.; Gleich, B. Improving heat generation of magnetic nanoparticles by pre-orientation of particles in a static three tesla magnetic field. J. Magn. Magn. Mater. 2017, 427, 195-199. [CrossRef]

26. Bayerl, T.; Duhovic, M.; Mitschang, P.; Bhattacharyya, D. The heating of polymer composites by electromagnetic induction-A review. Compos. Part A 2014, 57, 27-40. [CrossRef]

27. Apostolidis, P.; Liu, X.; van de Ven, M.; Erkens, S.; Scarpas, T. Control the crosslinking of epoxy-asphalt via induction heating. Int. J. Pavement Eng. 2019, 8436. [CrossRef]

28. Meffre, A.; Mehdaoui, B.; Kelsen, V.; Fazzini, P.F.; Carrey, J.; Lachaize, S.; Respaud, M.; Chaudret, B. A simple chemical route toward monodisperse iron carbide nanoparticles displaying tunable magnetic and unprecedented hyperthermia properties. Nano Lett. 2012, 12, 4722-4728. [CrossRef]

29. Caetano, P.M.A.; Albuquerque, A.S.; Fernandez-Outon, L.E.; Macedo, W.A.A.; Ardisson, J.D. Structure, magnetism and magnetic induction heating of NixCo(1-x)Fe2O4 nanoparticles. J. Alloys Compd. 2018, 758, 247-255. [CrossRef]

30. Bordet, A.; Lacroix, L.M.; Soulantica, K.; Chaudret, B. A New Approach to the Mechanism of Fischer-Tropsch Syntheses Arising from Gas Phase NMR and Mass Spectrometry. ChemCatChem 2016, 8, 1727-1731. [CrossRef]

31. Verde, E.L.; Landi, G.T.; Gomes, J.A.; Sousa, M.H.; Bakuzis, A.F. Magnetic hyperthermia investigation of cobalt ferrite nanoparticles: Comparison between experiment, linear response theory, and dynamic hysteresis simulations. J. Appl. Phys. $2012,111$. [CrossRef]

32. Vinum, M.G.; Almind, M.R.; Engbæk, J.S.; Vendelbo, S.B.; Hansen, M.F.; Frandsen, C.; Bendix, J.; Mortensen, P.M. Dual-Function Cobalt-Nickel Nanoparticles Tailored for High-Temperature Induction-Heated Steam Methane Reforming. Angew. Chem. Int. Ed. 2018, 57, 10569-10573. [CrossRef] [PubMed] 
33. Verde, E.L.; Landi, G.T.; Carrião, M.S.; Drummond, A.L.; Gomes, J.A.; Vieira, E.D.; Sousa, M.H.; Bakuzis, A.F. Field dependent transition to the non-linear regime in magnetic hyperthermia experiments: Comparison between maghemite, copper, zinc, nickel and cobalt ferrite nanoparticles of similar sizes. AIP Adv. 2012, 2. [CrossRef]

34. Wang, W.; Tuci, G.; Duong-Viet, C.; Liu, Y.; Rossin, A.; Luconi, L.; Nhut, J.M.; Nguyen-Dinh, L.; Pham-Huu, C.; Giambastiani, G. Induction Heating: An Enabling Technology for the Heat Management in Catalytic Processes. ACS Catal. 2019, 9, 7921-7935. [CrossRef]

35. Cullity, B.D.; Graham, C.D.G. Introduction to Magnetic Materials; Wiley: Hoboken, NJ, USA, 2009.

36. Morales, I.; Muñoz, M.; Costa, C.S.; Alonso, J.M.; Silva, J.M.; Multigner, M.; Quijorna, M.; Ribeiro, M.R.; de la Presa, P. Induction heating in nanoparticle impregnated zeolite. Materials 2020, 13, 4013. [CrossRef]

37. De La Presa, P.; Luengo, Y.; Multigner, M.; Costo, R.; Morales, M.P.; Rivero, G.; Hernando, A. Study of heating efficiency as a function of concentration, size, and applied field in $\gamma$-Fe2O3 nanoparticles. J. Phys. Chem. C 2012, 116, 25602-25610. [CrossRef]

38. Costa, C.S.; Muñoz, M.; Ribeiro, M.R.; Silva, J.M. A thermogravimetric study of HDPE conversion under a reductive atmosphere. Catal. Today 2020. [CrossRef]

39. Figueiredo, J.L.; Pereira, M.M.; Faria, J. Catalysis from Theory to Application; Coimbra University Press: Coimbra, Portugal, 2008. [CrossRef]

40. Etim, U.J.; Xu, B.; Zhang, Z.; Zhong, Z.; Bai, P.; Qiao, K.; Yan, Z. Improved catalytic cracking performance of USY in the presence of metal contaminants by post-synthesis modification. Fuel 2016, 178, 243-252. [CrossRef]

41. Levecque, P.; Gammon, D.W.; Jacobs, P.; Vos, D.; Sels, B. The use of ultrastable Y zeolites in the Ferrier rearrangement of acetylated and benzylated glycals. Green Chem. 2010, 828-835. [CrossRef]

42. Bacariza, M.C.; Graça, I.; Lopes, J.M.; Henriques, C. Enhanced activity of CO2 hydrogenation to CH4 over Ni based zeolites through the optimization of the Si/ Al ratio. Microporous Mesoporous Mater. 2018, 267, 9-19. [CrossRef]

43. Wong, S.; Ngadi, N.; Abdullah, T.A.T.; Inuwa, I.M. Catalytic Cracking of LDPE Dissolved in Benzene Using Nickel-Impregnated Zeolites. Ind. Eng. Chem. Res. 2016, 55, 2543-2555. [CrossRef]

44. Caldeira, V.P.S.; Santos, A.G.D.; Oliveira, D.S.; Lima, R.B.; Souza, L.D.; Pergher, S.B.C. Polyethylene catalytic cracking by thermogravimetric analysis: Effects of zeolitic properties and homogenization process. J. Therm. Anal. Calorim. 2017, 130, 1939-1951. [CrossRef]

45. Coelho, A.; Costa, L.; Marques, M.M.; Fonseca, I.M.; Lemos, M.A.N.D.A.; Lemos, F. Applied Catalysis A: General The effect of ZSM-5 zeolite acidity on the catalytic degradation of high-density polyethylene using simultaneous DSC / TG analysis. Appl. Catal. A Gen. 2012, 413-414, 183-191. [CrossRef]

46. Gonzalez-Fernandez, M.A.; Torres, T.E.; Andrés-Vergés, M.; Costo, R.; de la Presa, P.; Serna, C.J.; Morales, M.P.; Marquina, C.; Ibarra, M.R.; Goya, G.F. Magnetic nanoparticles for power absorption: Optimizing size, shape and magnetic properties. J. Solid State Chem. 2009, 182, 2779-2784. [CrossRef] 